\title{
Peculiar clinical presentation of primary syphilis in the oral cavity
}

\begin{abstract}
- Jefferson da Rocha Tenório Oral Pathology Department, School of Dentistry, University of São Paulo, São Paulo, SP, Brazil • Letícia Drumond de Abreu Guimarães Oral Pathology Department, School of Dentistry, University of São Paulo, São Paulo, SP, Brazil • Bruno Fernandes Matuck Oral Pathology Department, University of São Paulo, São Paulo, SP, Brazil • Thalita Santana Conceição Oral Pathology Department, School of Dentistry, University of São Paulo, São Paulo, SP, Brazil • Matheus Sampaio de Oliveira Dental Clinic Department, University of Juiz of Fora, Minas Gerais, MG, Brazil • Suzana Cantanhede Orsini Machado de Sousa Oral Pathology Department, School of Dentistry, University of São Paulo, São Paulo, SP, Brazil
\end{abstract}

ABSTRACT | Syphilis, a sexually transmitted infection, has increased in incidence over the years, especially among the adult population. The oral manifestation of primary syphilis is usually characterized by a clinical course variable in which it progresses to the next stages if not treated. In this report, we present two cases of oral manifestation of primary syphilitic lesion with peculiar clinical characteristics, and we emphasize the importance of a correct diagnosis. Biopsies were needed for differential diagnosis and serological exams were requested. The histopathological analysis suggested the diagnosis and the immunohistochemistry confirmed the presence of Treponema pallidum. Antibiotic therapy was initiated with complete remission of the lesion. Therefore, a thorough anamnesis and a thorough clinical examination are essential for establishing the correct diagnosis, to begin the treatment of syphilis as soon as possible, thus avoiding the disease's progression.

DESCRIPTORS | Syphilis; Infection; Treponemal Infections.

RESUMO | Apresentação clínica peculiar de sífilis primária na cavidade oral • A sífilis, uma infecção sexualmente transmissível, aumentou sua incidência ao longo dos últimos anos, especialmente entre a população adulta. A manifestação oral da sífilis primária é geralmente caracterizada por um curso curto, no qual ela não é tratada e progride para os próximos estágios. Neste relato, apresentamos dois casos de manifestação oral de lesão sifilítica primária com apresentação clínica peculiar e enfatizamos a importância do diagnóstico correto. Biópsias foram necessárias para diagnóstico diferencial e exames sorológicos foram solicitados. A análise histopatológica sugeriu o diagnóstico, e a imuno-histoquímica confirmou a presença do Treponema pallidum. Antibioticoterapia foi iniciada com remissão completa da lesão. Portanto, anamnese e um exame clínico minuciosos são essenciais para estabelecer o diagnóstico correto, a fim de estabelecer o tratamento da sífilis o quanto antes, evitando-se assim a progressão da doença.

DESCRITORES | Sífilis; Infecção; Infecções por Treponema.

CORRESPONDING AUTHOR ～• Jefferson da Rocha Tenório Department of Oral Pathology and Special Care Patients, Dentistry School, São Paulo University São Paulo, SP, Brazil • Av. Prof. Lineu Prestes, 2227 São Paulo, SP, Brazil • 05508-900 E-mail: jeffersonrtenorio@usp.br

- Received Oct. 9,2018 • Accepted Jan. 29, 2019

• Dol http://dx.doi.org/10.11606/issn.2357-8041.clrd.2019.150981 


\section{INTRODUCTION}

Despite having been almost eradicated in some countries a few decades ago, syphilis has re-emerged and today constitutes an endemic health problem in many countries. Thus, currently it is not uncommon for a health professional to encounter lesions caused by Treponema pallidum. ${ }^{1}$ Syphilis' etiologic agent is the bacteria known as Treponema pallidum that can enter the body through different ways, usually transmucosal, most frequently via the genital mucosa followed by the oral mucosa. The origin of syphilis has been discussed in forums throughout the world; however, what is new is that its evolution had a great impact on the lifestyle of American and European societies. Some studies reported that $8-14 \%$ of the American population was infected in the beginning of the 2oth century. ${ }^{2}$

After the first infection, if untreated, syphilis progresses trough three stages: primary, secondary, and tertiary. ${ }^{3}$ The first stage corresponds to the formation of a characteristic, unique chancre, on the place of sexual contact. In addition to the chancre, the patients usually develop lymphadenopathy, weakness and fever. ${ }^{4}$ The genital mucosa is the most commonly affected, but in about $5 \%$ of the cases the lesion may be found on other parts of the genitalia, the oral mucosa being responsible for $40-75 \%$ of these other genital lesions. ${ }^{4}$

The first reports in the literature of a primary syphilitic chancre in oral mucosa date from 1970. The lower lip in particular is the most affected site, where the lesion appears as a vegetative ulcer, which lasts for 4-6 weeks. ${ }^{5}$ The clinical aspect of the chancre can lead the clinician towards diverse types of differential diagnosis, such as infectious diseases (tuberculosis, paracoccidioidomycosis) and squamous cell carcinoma. Usually, without a detailed anamnesis, a hypothesis of syphilis will be unlikely. However, due to the rarity of primary oral syphilitic lesions, a biopsy will be performed in many instances, and thus, the role of the oral pathologist in diagnosing the disease is crucial. ${ }^{6}$
In this study, we report two cases of primary lesion of syphilis on the tongue and buccal mucosa and on the lip, primarily diagnosed by the oral pathologist.

\section{CASE REPORT}

\section{Case 1}

A previously healthy 56-year old man went to the hospital's outpatient clinic for further examination of a large bleeding, painful ulcer that extended from the left lip commissure to the central region of the buccal mucosa. During the clinical examination, a vegetative ulcer with restricted borders covered by a fibrinopurulent membrane was noted. The lesion had $3 \mathrm{~cm}$ in extension and had been present for unknown time (Figure 1A); however, according to the patient, it had increased in size in the last 10 days, when the patient decided to see a health professional. In addition to the lesion, the patient had constitutional signs suggestive of systemic infection such as lymphadenopathy, loss of appetite and low fever. He denied any previous sexually transmitted infection, as well as oral sexual contact. Thus, as there was suspicion of infectious diseases, incisional biopsies were performed. The histopathological analysis showed an ulcerated mucosa, covered by a fibrinopurulent membrane, and with a dense connective tissue on the lamina propria that showed a high population of plasma cells, macrophages and lymphocytes. Granulation tissue, characterized by multiple capillaries surrounded by endothelial cells, was also present, especially below the ulcerated area. Extravasation of red blood cells was noted (Figure 1B). Due to the massive presence of plasma cells, especially in the surrounding vessels, an immunohistochemical reaction against Treponema pallidum (ab20923, Abcam, Cambridge, MA, U.S.A.) was induced in $4 \mu \mathrm{m}$ sections paraffin embedded material. A large number of positively stained spirochetal microorganisms, compatible with spirochetes, were both scattered on the connective tissue and located perivascularly (Figure 1C). 

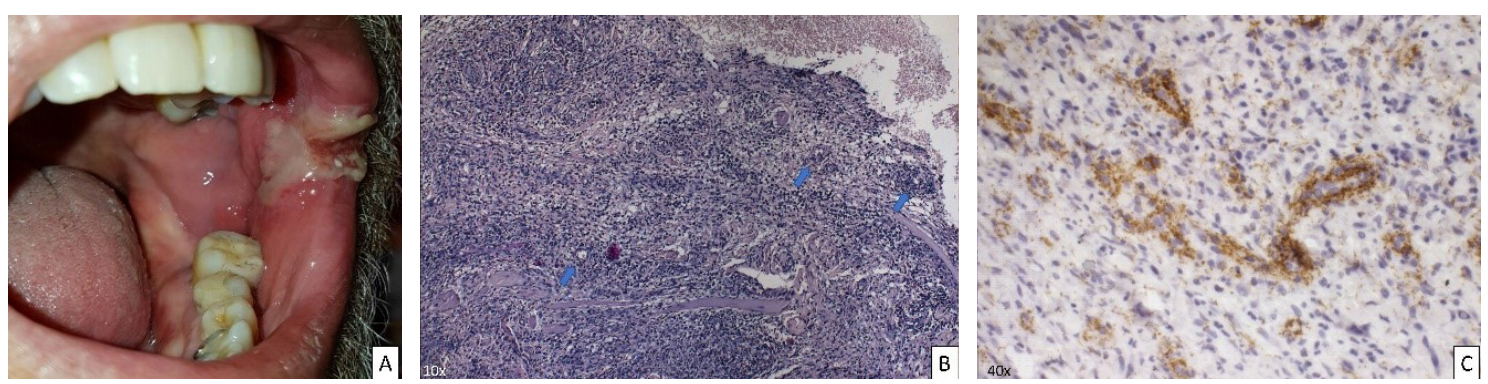

Figure 1 | Clinical, histopathological and immunohistochemical assessment. A) A large ulcer that extends from the left lip commissure to the buccal mucosa's central region; B) The hematoxylin and eosin stain (10x) shows a dense connective tissue with a high population of plasma cells, macrophages and perivascular lymphocytes (blue arrows); C) Immunohistochemical reaction against Treponema pallidum (40x) that revealed a large number of positively stained spirochetes scattered on the connective tissue and located perivascularly (in brown).

The patient was submitted to serological exams such as Venereal Disease Research Laboratory (VDRL) and FTA-ABS, having tested positive for both. He was referred to an infectologist who treated him with an intramuscular injection of G-penicillin (2.400.000 UI), and complete remission of the lesions occurred in a few days.

\section{Case 2}

A 22-year-old female sought the medical services for evaluation of a unique oral lesion that had been evolving in the last four months with a sudden growth spike in last few days, which caused a burning sensation as well as pain. At the clinical examination, extensive ulceration was observed, covered by a fibrinopurulent membrane that felt firm when palpated, extending from the right anterior dorsum of the tongue to the ventral surface (Figure 2A). The lesion had $3 \mathrm{~cm}$ in extension associated with regional lymphadenopathy.
However, the patient had no other systemic alterations indicative of infectious diseases. Incisional biopsy was performed and the histopathological analysis showed an ulcerated mucosa, covered by a fibrinopurulent membrane and with a high population of macrophages and lymphocytes in the lamina propria (Figure 2B). These cells having been observed near the surrounding vessels, an immunohistochemical reaction against Treponema pallidum (ab20923, Abcam, Cambridge, MA, U.S.A.) was induced. There was also presence of positively stained spirochete microorganisms (Figure $2 \mathrm{C}$ ). In addition to the biopsy, serological exams such as Venereal Disease Research Laboratory (VDRL) and FTA-ABS were also requested, the results of both having been positive. The patient was referred to an infectologist who started treatment with an intramuscular injection of G-penicillin (2.400.000 UI), and complete remission of the lesions occurred in a few days.
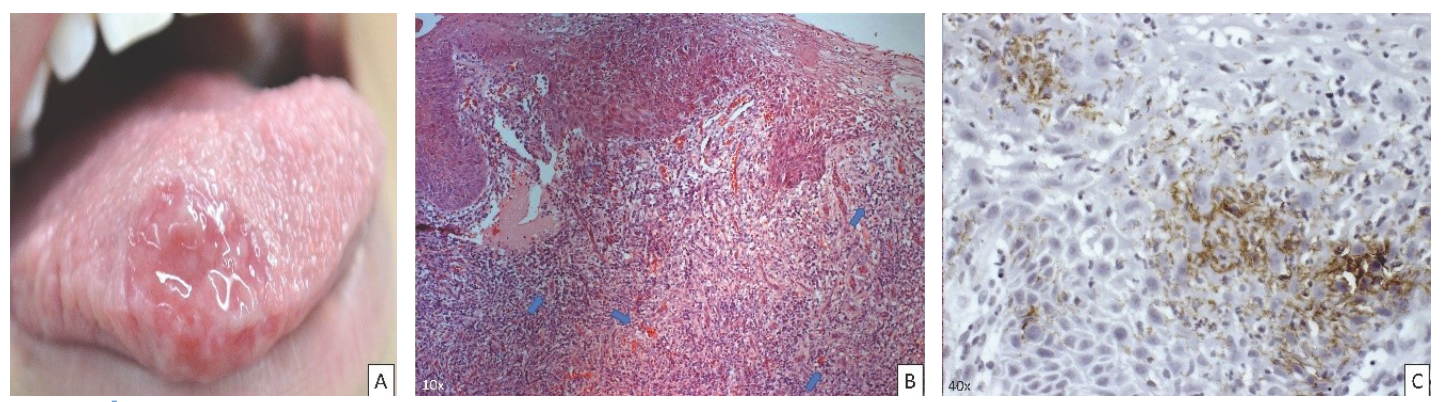

Figure 2 | Clinical, histopathological and immunohistochemical assessment. A) Extensive ulceration was observed, covered by a fibrinous membrane, located on the lateral border of the tongue extending from the apex of the base to the ventral surfaces.; B) The hematoxylin and eosin stain (10x) shows a high population of plasma cells, macrophages and perivascular lymphocytes (blue arrows); C) Immunohistochemical reaction against Treponema pallidum (40x), where many spirochetes were revealed (in brown). 


\section{DISCUSSION}

Primary syphilis commonly occurs in the genital region but it can also develop in extragenital regions, including the lips, tongue, palate, conjunctiva, neck, breasts, arms, palms and fingers. ${ }^{7}$ Oral manifestations of syphilis may represent a diagnostic challenge because of its wide spectrum of clinical appearances. ${ }^{8}$ In both cases, the diagnosis of syphilis was not considered at first because the patient had a single lesion with clinical characteristics that were not restricted to syphilitic chancres, since other neoplastic lesions, such as epidermoid carcinoma, or infectious lesions, such as tuberculosis, feature an overlap of clinical manifestations that may hinder diagnosis. One factor that contributes to the difficulty of diagnosis was the absence of reports of previous oral sexual contact. Here, we highlight the importance of interdisciplinary relations between the clinician and the oral pathologist, who should work together to obtain the necessary information to achieve an early diagnosis and establish the best management of these lesions.

Primary syphilis is characterized by a chancre that appears on the site of contact from 10 to 90 days after infection with Treponema pallidum. Regional lymphadenopathy develops a week after the appearance of the chancre. This chancre is generally solitary and infrequently occurs in the mouth. The erosion is indistinct at the edges, and the tissue in the middle is bright red in color, with a film layer that looks like polish on which the serosity develops, and a base that feels firm when palpated.,78 In both cases, the patients had a large ulcer, associated with regional lymphadenopathy, in addition to the absence of lesions involving the genital areas. Because oral ulcers are extremely common, it is important for the dentist to consider chancre in the differential clinical diagnosis of a persistent, non-healing oral ulcer.

The diagnosis of syphilis is usually based on clinical, microscopic and serologic findings. The serologic test is essential inasmuch as the clinical and microscopic findings are variable and relatively nonspecific. ${ }^{9110}$ The diagnosis of syphilis from oral lesions is becoming relatively frequent as the number of cases of the disease increases. Thus, oral pathologists and dentists are now more familiarized with the histological aspects that are suggestive of syphilitic lesion and, with the aid of a primary anti-treponemal antibody, the diagnosis can be confirmed. ${ }^{6}$ Although in our experience we have seen many biopsies of syphilis, mostly of secondary lesions, both cases were remarkable due to the intense presence of spirochetes as revealed by the anti-treponemal antibody.

The early diagnosis of syphilis is important as treatment is easy and avoids more severe complications and the spread of the disease or congenital syphilis. ${ }^{11}$ In this report, the patients were treated with a single dose of penicillin $\mathrm{G}$ injected intramuscularly, which was effective and resulted in the ulcer's healing and improvement of the clinical condition without sequelae.

\section{CONCLUSION}

Given the resurgence of syphilis in recent decades, oral healthcare providers should include the oral manifestation of syphilis among the differential diagnostic possibilities for a persistent oral mucosal ulceration or erosion, even in cases where the patient denies associated sexual activity.

\section{REFERENCES}

1. Ficarra G, Carlos R. Syphilis: the renaissance of an old disease with oral implications. Head Neck Pathol. 2009 Sept; 3(3):195-206. doi: 10.1007/s12105-009-0127-0.

2. Tramont EC. Syphilis in Adults: from Christopher Columbus to Sir Alexander Fleming to AIDS. Clin Infect Dis. 1995 Dec;21(6):1361-9. doi: 10.1093/clinids/21.6.1361

3. Stamm LV. Syphilis: Re-emergence of an old foe. Microb Cell. 2016 Jun;3(9):363-70. doi: 10.15698/mic2016.09.523.

4. Carneiro J, Alcino L, Porter SR. Review oral manifestations of syphilis. Clinics. 2006;61(2):161-6. 
5. Centers for Disease Control and Prevention. Sexually transmitted diseases treatment guidelines, 2006. MMWR 2006;55(2):1-9.

6. Siqueira CS, Saturno JL, de Sousa SC, da Silveira FR. Diagnostic approaches in unsuspected oral lesions of syphilis. Int J Oral Maxillofac Surg. 2014 Dec;43(12):1436-40. doi: 10.1016/j.ijom.2014.09.014.

7. Fukuda H, Takahashi M, Kato K, Oharaseki T, Mukai H. Multiple primary syphilis on the lip, nipple-areola and penis: an immunohistochemical examination of Treponema pallidum localization using an anti-T. pallidum antibody. J Dermatol. 2015 May;42(5):515-7. doi: 10.1111/13468138.12818 .
8. Demir FT, Salaeva K, Altunay IK, Yalcın O. An extraordinary case of syphilis presenting with a labial ulcer. Saudi Med J. 2016 Nov;37(11):1261-4. doi: 10.15537/smj.2016.11.15674.

9. Domantay-Apostol GP, Handog EB, Gabriel MT. Syphilis: the international challenge of the great imitator. Dermatol Clin. 2008 Apr;26(2):191-202. doi: 10.1016/j.det.2007.12.001.

10. Kelner N, Rabelo GD, da Cruz Perez DE, Assunção JN Jr, Witzel AL, Migliari DA, et al. Analysis of nonspecific oral mucosal and dermal lesions suggestive of syphilis: a report of 6 cases. Oral Surg Oral Med Oral Pathol Oral Radiol. 2014;117(1):1-7. doi: 10.1016/j.oooo.2012.04.028.

11. Workowski KA, Bolan GA. Sexually transmitted diseases treatment guidelines, 2015. MMWR. 2015 June;64(3):1-137. 